\title{
Central Nervous System Anaplastic Large Cell Lymphoma, ALK-Negative
}

National Cancer Institute

\section{Source}

National Cancer Institute. Central Nervous System Anaplastic Large Cell Lymphoma, ALKNegative. NCl Thesaurus. Code C129599.

An anaplastic large cell lymphoma, ALK-negative, arising from the central nervous system. 